\title{
The Consept Of Memorizing Hadith based Cooperative Social At Elementary Islamic School
}

\author{
Nurul Malikah ${ }^{1}$, Abdah Munfaridatus $\mathbf{S}^{\mathbf{1}}$, Medina Nur Asyifah Purnama ${ }^{1}$ \\ ${ }^{1}$ Institut Agama Islam Sunan Giri, Ponorogo \\ *Corresponding email: nurul.malikah1234@gmail.com
}

Naskah diterima: 27 Maret 2021 | Disetujui: 11 April 2021 | Diterbitkan: 12 Mei 2021

\begin{abstract}
The importance of memorizing hadiths in Islamic elementary schools is able to invite students to remember hadiths permanently for a long time. However, the acquisition of permanent memorization results is only possessed by students who concentrate well when watching the teacher repeat the hadith. This study describes the step of collaborative learning to memorize hadiths to improve memorizing results for all students in the class. This research describes; 1 concept of collaborative learning to improve the ability to memorize hadiths; 2 . To explain the steps in collaborative learning memorize the hadith in Islamic elementary school. 3. This research is analyzed based on the research description of the literature review on the principle of cooperation as a social ability and the principle of memorizing as cognitive abilities internalized to facilitate memorizing hadiths without leaving the value of cooperation. The result is that the concept of collaborative learning memorizes hadiths called SRAD GO, namely Seeing, Relating, Associating, Defending and Goal as community learning memorizing group hadiths
\end{abstract}

Keywords: memorizing hadith, cooperative learning, elementary islamic school

\begin{abstract}
Abstrak
Pentingnya menghafal hadits di sekolah dasar Islam mampu mengajak siswa untuk mengingat hadits secara permanen dalam waktu yang lama. Akan tetapi, perolehan hasil hafalan permanen tersebut hanya dimiliki oleh siswa yang berkonsentrasi dengan baik ketika melihat seorang guru dalam mengulang hadits. Penelitian ini menjelaskan tentang langkah pembelajaran kolaboratif untuk menghafal hadits untuk meningkatkan hasil hafalan bagi seluruh siswa di kelas. Penelitian ini menjelaskan; 1 konsep pembelajaran kolaboratif untuk meningkatkan kemampuan menghafal hadits; 2. Menjelaskan langkah-langkah pembelajaran kolaboratif menghafal hadits di sekolah dasar Islam. 3. Penelitian ini dianalisis berdasarkan uraian penelitian tinjauan pustaka tentang prinsip kerjasama sebagai kemampuan sosial dan prinsip menghafal sebagai kemampuan kognitif yang diinternalisasikan untuk memudahkan menghafal hadits tanpa meninggalkan nilai kerjasama. Hasilnya adalah konsep pembelajaran kolaboratif menghafal hadits yang disebut SRAD GO, yaitu Melihat, Menghubungkan, Mengasosiasi, Mempertahankan dan dengan Tujuan sebagai komunitas pembelajaran penghafal hadits secara kelompok.
\end{abstract}

Kata Kunci: hafalan hadits, pembelajaran kooperatif, sekolah dasar Islam 


\section{Introduction}

At this time learning memorization requires repairs to maintain memorization to last longer and permanently. Memorizing conditions need attention because according to (Leila Cheblia, 2014) revealed that memorizing is closely related to the ability to describe clear and structured verbal exposure. Only students who are able to memorize concepts can clearly describe and relate exposure between concepts.

Research conducted by (Elaheh Sadat Lajooee dan Shaban Barimani, 2013) about memorizing foreign (English) language vocabulary in Iran highlights the importance of memorizing languages through role playing in groups. This is also supported by (Nenkova, 2007) put forward about the complexity of memorizing vocabulary in a foreign language. It is suspected that the impact of recall depends on the length of time in preparing the task of learning to memorize and remember material. This is done by testing the memorizing ability which turns out to be complicated in recalling the material that has been tested.

Reviewing the importance of memorizing learning, memorizing needs to involve supporting activities through various methods to improve memorization responses faster and can be stored longer (Mark Blair dan Don Homa, 2003). The importance of accelerating learning to memorize shows an increase in social skills and cognitive academic abilities of students so that it can facilitate completing tasks in other learning activities in achieving mental skills (Nazia Nawaz, 2015). Memorizing is the cognitive competence that will be achieved in the learning of hadith in the hope that the memorization obtained becomes the foundation of the application of material in everyday life (Elaheh Sadat Lajooee dan Shaban Barimani, 2013). Therefore it is considered important that there be improvements in memorizing methods that are easy and permanent.

Maghtawi, dkk. (Magthwi, 2015) (Ashaari, 2015) elaborates that the improvement in the ability to interpret hadith is measured through intercorrelation which is associated with increasing the ability to understand hadith texts with correct reading. Similar things were conveyed by (Nor Musliza Mustafa, 2014),(Mahbobi, 2014) that to improve the ability to memorize foreign texts (hadith) requires the support of pleasant tools in the form of hardware and guidelines for teaching materials that help the learning process to avoid sound errors when reading.

Achievement of the correct learning outcomes of memorization must be adjusted to the program plan set based on the principle of memorizing the evaluation set by the teacher (Diab Hamadneh, Iyad Mohammed Jordan Mafraq, 2014). Memorizing results have not been achieved maximally with the KKM boundary during the learning process, because the acquisition of learning outcomes is only achieved by students who have good abilities who are highly motivated.

Dimensional evaluation of reading hadiths dependent on Arabic pronoun and tajwid as a guide to correct reading (Siti Salwa Md.Sawari1, 2014). (Mohyuddin, 2014); (Salako Taofiki Ajani, 2013) suggest clear guidelines for regulating the memorization process in stages in repeating sequential words in order to find out the learning outcomes during conducive interactions. Memorizing learning by MI teachers tends to use the method of repeating the hadith lafad so that the tartil recitations are appropriate, and loud and loud so that students do not lose concentration during the memorization process. There needs to be a clear role in memorizing which can make it easier for students to compile pieces of words so they can be stored and repeated memorization and used based on categorization or word classification (Mahbobi, 2014);(Nor Musliza Mustafa, 2014). In this case, it is necessary to 
have a structured way of learning memorizing to maintain concentration, in the hope that it can minimize the noisy and crowded atmosphere during the learning process because not all students are able to tolerate the noisy atmosphere in the learning process.

\section{Islamic elementary school}

Third-grade, fourth-grade and ninth-graders are able to collaborate to achieve goals and have mutual dependency in completing tasks, and tend to produce greater achievements than goals through dependence in the attitude of cooperation, academic support, and personal, so that they have the ability to respond to members other groups (Bertucci, Johnson, Johnson, \& Conte, 2016), (Gillies, 2003).

\section{Cooperative Correlation}

Research of (Janne E. Trempy, 2002) concluded that the success of cooperative learning can improve learning outcomes up to $90 \%$, so students have the ability to think critically, be able to solve problems, and have interacting skills and skills synthesizing problems related to the material.

Macarena summarizes the results of his research that increasing the ability of balanced collaboration with the achievement of practical collective goals because students are able to overcome initial fears and insecurities in learning because they have found challenging learning (Macarena Navarro-Pabloa, n.d.). Robyn M. Gillies (201) revealed that the role of the teacher must create conditions that affect students to be able to relate the previous information to the future, encourage students to explain reasoning and thinking so that they engage in dialogic exchanges between students who listen to each other when building and connecting ideas and having alternative variations.

The same expression (Thanh, 2014) states that teachers and students need cooperative methods that can help teachers review and help students memorize (Fekri, 2016). In fact, cooperative learning is a teaching method, inspires social skills through student interaction, and for improving language learning training. Even though (Fariha Gull, 2015) stated in his research that learning is not possible under empty conditions without information. In learning activities cooperation begins with memorizing to support each other towards achievement. Memory strategies are connected with vocabulary and speech that must be kept in mind, that is manifested in memorization while social strategies are focused on the interaction of important features of speaking skills (Tania Henriquez, $\mathrm{n}$ Harry Von, Victor Pena, 2017). Chang.et.al (1999) notes that cooperative learning strategies when used appropriately allow students to learn texts faster, memorize basic facts, and learn lower level skills.

Day stated the results of the study that collaboration is closely related to the social interaction of emotional development, language, self-regulation, and success of learning by considering the ability of skills and attitudes in academic performance even though in the early ages between seven to eight years (Day et al., 2016). 


\section{Methods}

Qualitative description analysis connects between memorizing learning and cooperative learning. Memorizing is cognitive ability, while cooperative learning is social ability. The memorizing process requires the support of various methods to improve faster memorization responses that can be stored for longer (Mark Blair dan Don Homa, 2003). Acceleration of memorization is important because it is able to show an increase in social skills and cognitive acoustic abilities so that students are able to complete other learning tasks including aspects of mental attitude skills (Nazia Nawaz, 2015). Cooperative learning is cooperative learning, according to (Bahman Motaei, 2014) this can be a good alternative to the general teaching methods practiced in Iran. The implication of this research is that teachers must create an atmosphere in the classroom by involving students in the learning process, encouraging them to reflect and ask questions, and create opportunities for interaction between students and teachers. Both have relevant relationships related to mutually supportive learning. (Ghoreisi. Monir kalantar, Kargar, Flor rezaei, Ajilchi, 2019) explain the effect of cooperative methods to increase the positive effect of this collaboration method on working memory capacity that occurs by increasing the amount of information storage and improving the quality of student information processing. Friendship interventions and real tasks in cooperative learning deepen memory. This means that cooperative learning affects a person's memory capacity. The result is a learning step as a correlation between memorizing learning and cooperative learning.

\section{Result}

The results of the analysis obtained from literature review in learning memorizing hadith through cooperative learning are cooperative memorizing learning steps applied in Islamic elementary schools. The steps obtained by this model are:

\section{a) Seeing}

Description of the results of observing activities carried out by students during the learning process memorizing through a collaborative model to memorize third-class hadiths is that children begin to understand the images of congregational prayer carefully. It appears that the congregation hadiths had been studied last week. Observation of students on the picture began to be familiar and understand the activities that will be done. Students make observations at each step of the activity syntax when the process changes (carved) holding the image. Third graders enjoy every step that all students go through.

The results description in the fourth grade when students see or observe is to receive hadith material to be discussed, namely piety. Students have made groups as instructed by the teacher based on the count. Students begin to sit sitting in their respective places and receive pictures shared by the teacher. Students begin to observe images and carve pictures to other group members. Some students are still reminded to immediately carve (rotate) images to other members. Group members also need help spelling out the pronunciation.

The result of the fifth grade description when observing is that students receive pictures and start observing images. The opportunity to observe images is an activity to save the lafad that will be memorized. Pictures and lafad have conformity of meaning so that it makes it easier to observe. 


\section{b) Relating}

Third grade students have succeeded in getting their friends to rank the lafad well without being helped by the teacher independently. After the teacher explains about the syntax and material, students can ask the teacher about things that have not been understood. The fourth grade in asking about the lafad that is too long is still in the form of many sentences, the teacher finally makes adjustments to make it easier for students to express. Student questions cause changes per lafad. Class five asks about the value to the teacher about the results of the memorization together or later. The teacher offers to the group what things students like to show their ability to memorize hadiths about helping their children.

\section{c) Asosisted}

Linking the lafad is the success of collaborating in relating material about prayer in congregation in the third grade, the result is that they have smoothly exchanged images. The mention of the hadith lafad is also more fluent than the first stage. There is already a friend's attention to justify the pronunciation mentioned incorrectly. The theme of piety for the fourth grade, in terms of communication, they are easier to concentrate on asking their friends to memorize well. The fifth class which discusses orphans has been synchronously concentrating between saying the lafad and exchanging images in an orderly manner. In general, noise occurs because of small things that often invite jokes and laughter in learning. When the repetition was repeated many times the students did not feel memorized by themselves.

The memorization in the group has been successful, so it is continued to memorize between groups. There was also a commotion in revealing each lafad together in one group and then being carved with another group.

\section{d) Defending}

In general the results of maintaining memorization are the ability of students to remember the lafad is done well by all students both kels 3, 4 and 5. While students can communicate with all members in the group and reorder correctly. How to learn to memorize together but how to show memorizing results can be done individually or together depending on the agreement. The way to display the results of memorizing in front for class 3 is that there are advanced ones, some are together, class 4 displays the memorized results in one class together, while for grade 5 all together.

\section{e) Goal}

Students in groups can successfully sort the pieces of the lafad in order as memorized results for each group member. Kroscek is carried out between students from memorized results that have been obtained during memorizing together. In general, all group members are able to assess their friends during the memorization process, both grade 3,4 and 5. All classes are able to assess group members when mispronouncing the lafad. Noise occurs with laughter that doesn't feel, learning becomes fun. 


\section{Conclusion}

The results of this study were to find the correlation of learning concepts memorizing using cooperative learning to facilitate memorizing hadiths in fourth grade students in Ibtidaiyah Madrasas. Memorizing activities become more fun and easy to do because the value of shared responsibility appears to master the hadith material. Social togetherness through collaboration is able to improve and invite each student to move, responding to the invitation to memorize together so as to carry out cognitive abilities. The steps taken in learning cooperation in memorizing hadith are seeing, inviting, connecting, maintaining memorized results, and successfully memorizing together.

\section{References}

Ashaari, W. A. F. binti W. M. K. M. F. (2015). The Concept of Recitation (Hafazan) and Rational in Teaching and Learning in Western and Islamic Perspective Proceeding of the International Seminar and Conference.

Bahman Motaei. (2014). On the Effect of Cooperative Learning on General English Achievement of Kermanshah Islamic Azad University Student. https://doi.org/10.1016/j.sbspro.2014.03.540

Bertucci, A., Johnson, D. W., Johnson, R. T., \& Conte, S. (2016). Effect of task and goal interdependence on achievement, cooperation, and support among elementary school students, 79, 97-99.

Day, S. L., Phillips, B., Sparapani, N., Ingebrand, S. W., McLean, L., Barrus, A., \& Kaschak, M. P. (2016). Reciprocal Effects of Self-Regulation, Semantic Knowledge, and Reading Comprehension in Early Elementary School. Wiley Online Library.

Diab Hamadneh, Iyad Mohammed Jordan Mafraq, B. D. D. A. (2014). The principles of measurement and evaluation from the perspective of the Holy Quran (analytic study). Journal of Education and Practice, 5 No.37.

Elaheh Sadat Lajooee dan Shaban Barimani. (2013). Contrastive Study on Learning Vocabulary through Role-play and Memorization among EFL Female Learners. Journal of Academic and Applied Studies, 3.

Fariha Gull, S. S. (2015). effect of Cooperative Learning on Student academic Achievement. Journal of Educational and Learning.

Fekri, N. (2016). Investigating the effect of Cooperative Learning Competitive Learning Strategies on The English Vocabulary Development of Iranian intermediate EFL Learners. English Language Teaching.

Ghoreisi. Monir kalantar, Kargar, Flor rezaei, Ajilchi, B. (2019). The effet of obined astery ooperative learning on working memory capacity self eficacy and academic achievement in grade skipping. Imprensa Da Universiodade de Coimbra.

Gillies, R. M. (2003). The effects of cooperative learning on junior high school students during small group learning. School of Education, The University of Queensland, Brisbane. 
Janne E. Trempy, M. M. S. and W. A. S. (2002). Learning Microbiology Through Cooperation: Designing Cooperative Learning Activities that PromoteInterdependence, Interaction, and Accountability,. Department of Microbiology, Oregon State University, Corvallis, Oregon 97331-3804, Microblology Education,.

Leila Cheblia, A. G. (2014). The Impact of the Effectiveness of Sponsorship on Image and Memorizing: Role of Congruence and Relational Proximity. Sosial Behavioral Science, 109.

Macarena Navarro-Pabloa, E. J. G.-S. (n.d.). Teaching to training teachers through cooperative learning.

Magthwi, A. A. Al. (2015). The Effectiveness Of Probing Questions Strategy In The Development Of Thinking Skills In The Islamic Education Courses Using A Sample Of Intermediate School Students In Riyadh. Journal European Scientific, 22 issn: .

Mahbobi, M. (2014). Comparing teaching of Islamic and Language subjects in Afghanistan (Teachers' views and use of strategies in grade 4 of schools in Ghor Province).

Mark Blair dan Don Homa. (2003). As easy to memorize as they are to classify: The 5-4 categories and the category advantage., Journal Memory \& Cognition,.

Mohyuddin, A. (2014). Structure and Organization of Al-Huda International: An Institution for Female Islamic Education. European Academic Research, II(5).

Nazia Nawaz, S. F. J. (2015). Effects of Memorizing Quran by Heart (Hifz) On Later Academic Achievement. Journal of Islamic Studies and Culture June, 3.

Nenkova, A. et all. (2007). To memorize or predict Prominance Labeling in Conversational speech. Association for Computational Linguistics.

Nor Musliza Mustafa, M. B. (2014). Memorization. E-Journal Glit Language Practice \& Information Technology.

Salako Taofiki Ajani, B. A. B. \& H. M. S. (2013). An Assessment Of The Concept, Content And Methodologies For Teaching Islamic Studies In Ogun State, Nigeria Between. Humanities and Social Science Invention ISSN.

Siti Salwa Md.Sawari1, M. Z. A. M. (2014). Harmonizing Al-Qabisy's View And Practice Of J-Qaf Programme In Malaysian Primary School Jurnal Asian Journal Of Management Sciences \& Education, 3.

Tania Henriquez, n Harry Von, Victor Pena, E. A. L. (2017). The effect of memory and Social Strategis on Oral Production. Colomb Appl Linguist.

Thanh, P. T. H. (2014). implementing Cross-Cultura Pedagogies. Spinger Singapore Heideberg. 
The Consept Of Memorizing Hadith based Cooperative Social At Elementary School Nurul Malikah, Abdah Munfaridatus S, Medina Nur Asyifah Purnama 